\title{
ЭКОЛОГИЧЕСКИЙ МОРСКОЙ ТУРИЗМ КАК ФАКТОР УСТОЙЧИВОГО РАЗВИТИЯ РУССКОЙ АРКТИКИ
}

\section{Грушенко Э.Б}

Институт экономических проблем им. Г.П. Лузина КНЦ РАН, Мурманск, grushenko.eduard@mail.ru

В соответствии со Стратегией развития Арктической зоны РФ до 2020 г. предусмотрено: «развитие арктического туризма и расширение экологически безопасных видов туристской деятельности в Арктике, совершенствование нормативно-правового обеспечения в сфере туризма, создание системы его финансовой поддержки на принципах государственно-частного партнёрства, содействие формированию региональных туристических кластеров, продвижение арктического туризма на национальном и международном рынках» [7].

Даже при слабом развитии инфраструктуры туризма в полярных широтах наблюдается устойчивый рост интереса к путешествиям в Арктику. Увеличение числа зарубежных туристов в Западной Арктике связано с проведением исследований в рамках научных экспедиций, с посещением труднодоступных, но уникальных по природным особенностям районов. Глобальное потепление с тающим морским льдом открывает больше арктических вод для круизных судов. Необходимо отметить, что проблемы развития туризма в Русской Арктике, обусловленные высокой стоимостью транспортных услуг, отсутствием соответствующей инфраструктуры, институциональными ограничениями передвижения (пограничный и таможенный контроль), а также с недостаточно высоким уровнем жизни населения в РФ, не позволяют рассчитывать на массовый высокоширотный арктический туризм в ближайшей перспективе.

Следует иметь в виду, что туризм в Русской Арктике имеет свою региональную специфику, связанную с особыми природно-климатическими условиями и необходимостью обеспечения надежной безопасности пребывания здесь туристов. Кроме этого, для арктических особо охраняемых природных территорий (ООПТ) вопрос доступности собственно территории представляется весьма важным, и составляющая морского либо воздушного путешествия в высокоширотную Арктику для туристов играет большую роль. Всё это усложняет организацию и проведение работ туристских компаний и не способствует повышению их экономической эффективности.

В целом можно отметить, что все действующие в Арктике туристские компании заинтересованы в том, чтобы присутствие человека в ранимой природе Арктики оказывало минимальное воздействие на природную среду, и природа оставалась бы в естественном состоянии, благоприятном для жизни животных, сохранившихся в этих диких для человека местах [3].

При разработке перспективных мероприятий, направленных на повышение привлекательности ООПТ высокоширотных западно-арктических архипелагов для целей развития туризма, следует исходить из особенностей географического расположения этих территорий. Прежде всего, следует учитывать отдалённость территории, островное морское расположение, суровые климатические условия и явно выраженную сезонность, что не позволяет говорить о возможности круглогодичного её посещения. Отдалённость территории от крупных транспортных узлов и приоритет использования морского транспорта для достижения островных территорий определяют большие расходы на организацию морских круизов, которые преобладают в арктическом туристском бизнесе.

Высокая стоимость морских круизов в зависимости от туроператора, класса судна, комфортности кают и длительности путешествия объективно сдерживает развитие арктического туризма для многих социальных групп населения внутри России. Стоимость туров для русских групп в Арктике в условиях обвальной девальвации рубля в целом представляется достаточно высокой, рассчитанной на сегмент людей с уровнем доходов выше среднего. Путешествия в Русскую Арктику должны стать доступны туристам с различным уровнем доходов. Чтобы улучшить транспортную доступность и снизить цены на путешествие, необходимо развивать конкуренцию в логистике и в транспортном обслуживании.

В целом же, позитивно оценивая имеющиеся возможности развития арктического туристского бизнеса в регионах Российской Арктики необходимо подчеркнуть, что возможности имеющего- 
ся ресурсного потенциала ООПТ используются далеко ещё не в полной мере. Актуальнейшей проблемой в практической деятельности организации турпотоков остаётся учёт оптимальной ёмкости ООПТ для принятия определённого количества туристов со всего мира с позиций экологии. Очень важно не навредить природе, не уничтожить уникальные природные и культурные объекты, учитывая не всегда высокий уровень экологического воспитания и культуры какой-то части туристов. Поэтому администрациями ООПТ вполне обоснованно вводятся разного рода ограничения, регламентируется количество и поведение туристов и паломников. Особого внимания требует посещение импактных районов, горячих экологических точек в Арктике, обеспечение безопасности и сохранение здоровья всех туристов. Баланс экономики и экологии в сфере арктического туризма не менее важен, чем в других отраслях [4].

Основными перспективными центрами арктического туризма в высоких широтах становятся архипелаг Шпицберген и национальный парк «Русская Арктика», организованный на архипелагах Земля Франца-Иосифа (ЗФИ) и Новая Земля. Архипелаги Шпицберген и ЗФИ могут стать одной из точек роста российского арктического туризма как геополитического фактора усиления присутствия России в Западной Арктике.

В настоящий период идет процесс организации национального парка «Русская Арктика», учрежденного в 2009 г. В состав парка включены северная часть архипелага Новая Земля, федеральный природный заказник «Земля Франца-Иосифа». Это самая северная и самая крупная морская особо охраняемая территория в Арктике, 85\% архипелага покрыто ледниками. В августе 2016 г. территория национального парка «Русская Арктика» была расширена на 7.4 млн. га. Расширение произошло за счет федерального заказника «Архипелаг Земля Франца-Иосифа» площадью 1.6 млн. га и участка внутренних морских вод и территориального моря России площадью 5.8 млн. га. Таким образом, национальный парк «Русская Арктика» стал самой большой в России ООПТ- площадью 8.8 млн. га. [5]. Это также самый крупный сухопутный национальный парк и морской природный резерват в России. Расширение парка будет способствовать сохранению арктических редких видов животных и птиц, внесенных в Красные книги России и мира, а также их местообитаний.

На территории парка располагаются крупнейшие в Северном полушарии птичьи базары, лежбища моржей, обитают белые медведи, грендландский кит, тюлени и нерпы. Парк создаётся для сохранения уникальной природы Арктики. Основным видом доставки туристов является морской круизный туризм, который является одной из стратегических задач развития национального парка.

В связи с созданием национального парка, ледокольные круизы на Северный полюс выполняются из Мурманска в последнее время в основном через ЗФИ, с заходом на Новую Землю. В летний сезон 2015 г. на территорию национального парка «Русская Арктика» выполнено 11 круизов. Из них -7 круизов на Северный полюс на атомном ледоколе «50 лет Победы» (является визитной карточкой арктического туризма, так как это - эксклюзивный российский турпродукт) с заходом на ЗФИ. Один из таких круизов на макушку планеты выкупили почти на 100 \% китайские туристы [1]. Общий туристский поток в национальный парк «Русская Арктика» составил в 2015 г. 1225 человек, что является рекордом посещаемости за всю историю круизов [5, 6]. В 2015 г. на архипелаге ЗФИ был открыт пограничный морской пункт пропуска для иностранных туристов в тестовом режиме, что позволяет упростить погранично-таможенные процедуры и сократить на трое суток путь круизных рейсов по транзитному маршруту от Шпицбергена на ЗФИ без захода судов в Мурманск или Архангельск. В 2015 г. Ростуризм и компания «Посейдон Экспедишн» впервые организовали три экспедиционных круизных тура для иностранных туристов (500 чел.) с посещением архипелагов Шпицберген и ЗФИ. Стоимость круиза составляет от 7 до 14 тыс. \$.

В 2017 г. посетило 1142 туриста [6]. Рост по сравнению с 2016 г. составил 20\% (табл. 1). В этом году в «Русскую Арктику» заходили круизные суда, следовавшие по трём маршрутам: 6 из Мурманска к Северному полюсу на атомном ледоколе «50 лет Победы»; 3 - на теплоходе «Sеa Spirit» по маршруту Шпицберген - Земля Франца-Иосифа. Два рейса на судне «Академик Шокальский» выполнены впервые в современной истории по всей протяженности Северного морского пути (Мурманск-Анадырь). Национальный состав пассажиров составил: 26 \%- китайские туристы, нем- 
цев - $17 \%$. Россиян - всего $6 \%$. Было два круиза с туристами из Франции. Стоимость участия в круизе на атомном ледоколе «50 лет Победы» составляет от 27 до 40 тыс. \$, в среднем на борту около 120 пассажиров [5, 6], всегда практически отмечается полная заполняемость судна.

Арктические круизы проходят в основном по территории архипелага ЗФИ, чуть реже посещается север Новой Земли. Туристы осматривают птичьи базары и наблюдают за арктическими животными на скале Рубини, в бухте Тихая, на островах Чампа и Рудольфа. Высадки с судна осуществляются на специальных резиновых моторных лодках типа «Зодиак» или с помощью вертолета. Массу впечатлений у путешественников оставляет высадка на остров Хейса, окруженный плавающими айсбергами и льдами. Вокруг бродят белые медведи, а на льдинах лежат огромные моржи - настоящая полярная экзотика. Необходимо отметить, что в круизах большое внимание уделяется бережному отношению к природе Арктики при организации высадок туристов на острова. Сохранение уникального ландшафтно-геологического и историко-культурного наследия национального парка стоит в центре внимания организаторов ледокольных круизов. Гости национального парка приняли участие в уборке мусора в бухте Тихая (остров Гукера), которая теперь полностью очищена от техногенного мусора. На каждом туристе национальный парк зарабатывает около 50 евро [5]. Этот доход может быть инвестирован в природоохранные проекты и в развитие инфраструктуры. «Русская Арктика» является главным оператором масштабной федеральной программы очистки Арктики от отходов, оставшихся со времени активной хозяйственной, научной и военной деятельности СССР на этих территориях.

Таблица 1. Морские круизы в национальный парк «Русская Арктика [6].

\begin{tabular}{|l|c|c|c|c|}
\hline & 2014 & 2015 & 2016 & 2017 \\
\hline Количество круизов & 6 & 11 & 9 & 11 \\
\hline Количество круизных туристов, чел. & 738 & 1225 & 954 & 1142 \\
\hline
\end{tabular}

Упрощение логистики, например, использование авиации позволит удешевить поездку в национальный парк и увеличить туристский поток. Создание многофункциональных арктических комплексов с вертолетными площадками в «Русской Арктике», которые могут посетить туристы и ученые, способно существенно снизить цену туров [2]. Так, в районе самой северной погранзаставы в мире - на острове Александры ЗФИ создаются объекты инфраструктуры оборонного значения, в том числе строится военный аэродром, который в перспективе можно использовать для организации авиатуров. Разрабатывается программа стационарного пребывания туристов на острове Александры, рассчитанная на 3-5 дней.

Специалисты национального парка рассчитывают на дальнейший рост полярного туризма. Создание постоянного пограничного пункта пропуска, организация экологических троп, музейных экспозиций, мини-гостиниц, смотровых площадок и визит-центров в национальном парке «Русская Арктика» будет способствовать увеличению заходов круизных судов, устойчивому развитию экологического туризма и росту туристского потока на первом этапе до 5-7 тыс. человек в год. В обозримом будущем количество туристов, посещающих национальный парк «Русская Арктика», может достичь 40-50 тыс. человек в год. Архипелаг Шпицберген ежегодно принимает около 76 тыс. туристов, из них примерно 30 \% готовы также посетить соседние российские заповедные территории: Новую Землю и ЗФИ [5]. Это практически нетронутые человеком территории со своим уникальным природным ландшафтом.

До недавнего времени на арктических островах практически отсутствовала какая - либо инфраструктура для развития массового туризма. Однако вскоре в национальном парке появятся четыре опорных пункта, в состав которых войдут визит - центры (три на ЗФИ и один на Новой Земле) и другие экологически безопасные инфраструктурные объекты. Предполагается построить смотровые площадки, туристские экологические тропы, информационные щиты и мини-гостиницы.

В национальном парке «Русская Арктика» создается первая экологическая тропа в бухте Тихая острова Гукера архипелага ЗФИ. Экологическая тропа поможет сохранить хрупкую экосисте- 
му бухты и упорядочить поток туристов. Вдоль тропы появится экспозиция самого северного музея в мире - музея под открытым небом «Живая история Арктики» на базе бывшей полярной станции. Создание интерактивной экспозиции нового визит-центра связано с планами национального парка по расширению комплекса туристских услуг в бухте Тихой. В последние годы уровень и перечень услуг для посетителей бухты значительно возросли. Здесь появилась сеть благоустроенных троп, туристская навигация, самая северная в мире почта и сувенирная лавка. Потребность в визит-центре назрела в связи с тем, что здесь одновременно высаживаются около 110 человек [6].

\section{Литература}

1. «Атомфлот» доставит на Северный полюс китайских туристов [Электронный ресурс]. Режим доступа: http://www.mvestnik.ru/shwpgn.asp?pid=2015071012 (дата обращения: 20.01.2017).

2. Глава национального парка «Русская Арктика» о туризме и летающих пингвинах [Электронный ресурс]. Режим доступа: https://lenta.ru/articles/2017/07/06/arctica/ (дата обращения: 20.09.2017).

3. Кузнецов В.С. Взгляд практика на состояние и перспективы развития туризма в западном секторе Российской Арктики // Арктический туризм в России / Отв. редактор издания Ю.Ф. Лукин, редактор Е.А. Шепелев, составитель справочника по регионам Н.К. Харлампьева. - Архангельск - Санкт-Петербург, 2016. C. $42-57$

4. Лукин Ю.Ф. Арктический туризм: рейтинг регионов, возможности и угрозы. [Электронный ресурс]. Режим доступа: http://narfu.ru/upload/iblock/274/09-_-lukin.pdf (дата обращения: 18.09.2017).

5. Сайт информационного агенства Арктика-Инфо [Электронный ресурс]. Режим доступа:http://www. arctic-info.ru/ (дата обращения: 12.01.2018).

6. Сайт национального парка «Русская Арктика» [Электронный ресурс]. Режим доступа: http://www. arctic-info.ru/ (дата обращения: 20.01.2018).

7. Стратегия развития Арктической зоны Российской Федерации и обеспечения национальной безопасности на период до 2020 года [Электронный ресурс]. Режим доступа: https://minec.gov-murman.ru/ activities/strat_plan/arkticzone/ (дата обращения: 21.08.2017). 